\title{
What carbon farming activities are farmers likely to adopt? A best-worst scaling survey
}

\author{
Nikki P.Dumbrella, Marit E.Kragtabc, Fiona L.Gibson ${ }^{\mathrm{ab}}$
}

a Centre for Environmental Economics and Policy, School of Agricultural and Resource Economics, The University of Western Australia, Crawley, WA, Australia

b Australian Research Council Centre of Excellence for Environmental Decisions, The University of Western Australia, Crawley, WA, Australia

${ }^{\mathrm{c}}$ Agriculture Flagship, Commonwealth Scientific Industrial Research Organisation (CSIRO), Perth, WA, Australia

\section{Highlights}

- We survey farmers to determine their willingness to adopt carbon farming practices

- Farmers are most likely to adopt practices that support production objectives

- Farmers consider improved soil quality as the most important benefit from carbon farming

- Best-Worst Scaling revealed preferences for retaining stubble and no-till cropping

- Policy uncertainty is a barrier to farmers' participating in carbon farming policy programs 


\title{
What carbon farming activities are farmers likely to adopt? A best-worst scaling survey
}

\begin{abstract}
Transferring carbon from the atmosphere into terrestrial sinks through carbon sequestration practices (so-called 'carbon farming') has been proposed as an important component in Australia's efforts to mitigate greenhouse gas emissions. We use a Best-Worst Scaling survey to determine which carbon sequestration practices farmers would be most and least likely to adopt, and what factors were most important in any potential adoption decision. The survey was distributed to dryland cropping and mixed crop-livestock farmers in Western Australia. Farmers ranked improved soil quality and reduced soil erosion as the most important potential co-benefits of carbon farming. Factors discouraging farmers from participating in carbon farming contracts were policy and carbon price uncertainty and the uncertain impact of carbon farming practices on productivity and profitability. Farmers had strong preferences for stubble retention and no-till cropping practices as carbon farming strategies. The practices that farmers preferred least were applying biochar and planting trees. Farm and farmer characteristics, including (lack of) awareness of carbon farming policies and opinions about climate change, influence the potential willingness to adopt different carbon farming practices. Given recent policy uncertainty and farmer preferences revealed in this study, it is important to communicate potential co-benefits (rather than opportunities to earn compensation or carbon credits) to increase farmers' engagement in carbon sequestration activities.
\end{abstract}

\section{Keywords}

Climate change mitigation, best worst ranking, stated preferences, broadacre farming systems, Australia 
2 To limit the potential impacts of climate change, the Australian government has set national greenhouse 3 gas (GHG) emissions reduction targets. The current reduction target (updated in August 2015) is 26428 percent below 2005 emissions by 2030 (Department of the Environment, 2015a). The Australian agricultural industry is responsible for 15-16 percent of national emissions (Department of the Environment, 2015b). As such, the industry is expected to contribute to national efforts towards emissions reductions.

Carbon farming is one way for farmers to reduce greenhouse gas emissions. 'Carbon farming' refers to a range of land use and land management practices designed to reduce emissions from farming activities, or sequester carbon in natural sinks such as soil and vegetation (Smith et al., 2008). In Australia, there are policies in place that include incentives to stimulate the adoption of carbon farming practices by landholders. The initial policy, the Carbon Farming Initiative (CFI), was introduced in 2011 (Parliament of the Commonwealth of Australia, 2011). For a two year period between July 2012 and July 2014 the initiative was working alongside a carbon price. The carbon price (indirectly) provided a value for carbon sequestration or GHG emissions reductions achieved by farmers. In December 2014, the CFI was merged into the new policy framework: the Emissions Reduction Fund (ERF, Parliament of the Commonwealth of Australia, 2014). The ERF operates as a reverse auction scheme. Under this scheme, farmers are invited to submit project bids that specify the carbon farming practices they are willing to undertake, and the required price per tonne of emissions reductions or sequestration to undertake the practice(s). The government purchase the lowest cost projects. For the CFI and ERF to be successful in mitigating climate change, it is imperative that farmers propose projects to participate in the scheme. Proposed projects must follow specific guidelines to ensure emissions reductions are measureable and verifiable. Under the ERF, the guidelines for projects are referred to as 'methods'. Some carbon farming practices that are covered by these methods include: reforestation of cleared lands; protecting native vegetation from being cleared; sequestering soil carbon in grazing systems; reducing emissions from livestock through changes in feed; and reducing emissions through improved fire management in northern savanna regions. ${ }^{1}$

The public benefits of carbon farming, such as greenhouse gas mitigation and potential positive impacts on biodiversity and hydrology, are important (Macintosh, 2013). Several studies have estimated the nonmarket values that society derives from farmers participating in environmental stewardship and conservation activities. For example, Rodríguez-Entrena et al. (2014) found that individuals have a positive willingness to pay (WTP) for erosion reduction and biodiversity benefits from carbon farming in Andalusian olive groves. Glenk and Colombo (2011) estimated WTP values for biodiversity benefits from implementing a soil carbon sequestration program in Scotland. Their estimates ranged between GBP 4 and GBP 41 for an "improvement of farmland bird habitat", which was used as a proxy for biodiversity values. In a study on co-benefits from carbon offsets in the aviation industry, MacKerron et al. (2009) also found positive WTP values for a "conservation and biodiversity" benefit.

\footnotetext{
1 See www.environment.gov.au/climate-change/emissions-reduction-fund/methods for a list of all approved methods under the ERF.
} 
Given the potential to deliver public benefits, it is not surprising that the policy interest in carbon farming is high. But, participation in carbon farming and emissions abatement policies is voluntary. So, what is in it for the farmer? There exists a rich literature on farmers' adoption of environmental management or conservation farming practices (e.g. Barr and Cary, 2000; Knowler and Bradshaw, 2007; Pannell et al., 2006). Factors that are important in farmers' decisions to change agricultural management practices include the (monetary and non-monetary) investment costs of the new practice, the impacts of the new practice on farm profitability, whether the practice 'fits' in the current farming system, the farmer's financial situation and personal values, the social context in which the farmer operates, as well as the public co-benefits generated by adopting the practice (Pannell et al., 2006; Kragt et al., 2014; Morgan et al., 2015). Generally, if new practices fit these criteria and provide (or are perceived to provide) private production benefits, farmers will adopt them (Morgan et al., 2015; Page and Bellotti, 2015). Carbon sequestration in agricultural soils can help to improve soil structure, reduce erosion, increase soil moisture retention and plant available water, and improve nutrient storing capacity (Desjardins et al., 2005; Lal, 2004). These changes can have a positive impact on agricultural yields (Kragt et al., 2012). Likewise, returning land to native vegetation can contribute to reduced salinity, improved water quality, and improved habitat provision for native plants and animals (George et al., 2012; Perring et al., 2012; Bradshaw et al., 2013). So, do farmers know of these potential benefits of carbon farming and are they using them as a motivator to adopt new management practices?

Despite the Australian government's interests in carbon farming, and the likely benefits of adoption, there have been few studies that have investigated whether farmers are willing to participate in carbon farming, and none that have looked specifically at the likelihood of Australian farmers adopting carbon sequestration practices within the context of the CFI and ERF, relatively unique policies. In this study we use a best-worst scaling survey to determine what carbon farming practices broadacre farmers are most likely to adopt. The focus of our research is on dryland cropping and mixed crop-livestock farmers, who form a significant part (28 percent) of Australia's farming community (Australian Bureau of Statistics, 2012). We also aim to identify the co-benefits and other factors that motivate or discourage farmers from adopting carbon farming practices.

The following section describes the best-worst scaling method. This is followed by a description of the survey design, sampling procedure, and modelling approach in Section 3. Results of the survey and best-worst scaling models are presented in Section 4. In the concluding section (Section 5), we discuss the findings in light of the CFI and ERF policy frameworks and develop recommendations for further work.

\section{The best-worst scaling method}

Best-worst scaling (BWS) is a survey-based, stated preference technique that presents respondents with sets of alternatives from which a respondent chooses his or her 'superior' and 'inferior' options (Finn and Louviere, 1992). The choice task is repeated over a number of sets that contain different 
combinations of the elements ${ }^{2}$, as per an experimental design. The repetition of varied choice sets and the choice task provides information to calculate the preference scores of each respondent (Jones et al., 2013). The likelihood of choosing an option is relative to the other options presented in the choice sets. It is expected that the most preferred options will be chosen as 'superior' more often than the other options and a least favoured option will be chosen more often as the 'inferior' option compared to the other alternatives.

An advantage of BWS is that choosing only a best and worst option from a set is often easier for respondents than ranking all the elements simultaneously. Another advantage is that the results typically show a greater discrimination between elements compared to alternative ranking techniques such as the Likert Scale (Finn and Louviere, 1992; Jones et al., 2013). Furthermore, other ranking techniques such as paired comparisons can be inadequate when the respondent is indifferent between the options or dislikes both options (Bateman et al., 2002).

Applications of BWS have been in food policy, food quality, health policy, transport and agricultural contexts (e.g. Coltman et al., 2010; Cross et al., 2012; Erdem et al., 2012; Glenk et al., 2014; Jones et al., 2013; Lee et al., 2007; Marti, 2012). The BWS technique has been used twice previously in agricultural GHG emissions mitigation studies. Jones et al. (2013) used BWS to elicit expert and farmer opinion on the relative effectiveness and practicality of practices to reduce GHG emissions from sheep farms in Wales. Glenk et al. (2014) used a BWS survey to rank 20 different greenhouse gas mitigation strategies for Scottish dairy farms to determine how current levels of adoption affected the perceived impacts of mitigation practices on farm performance. The authors found that current adoption rates significantly affected farmers' evaluation of potential carbon farming practices (Glenk et al., 2014). Our study is the first to use BWS to understand farmers' preferences to adopt carbon farming practices at the same time as a policy (the $\mathrm{CFI}$ ) is in operation to incentive the adoption of a sub-set of the practices.

\section{Survey design}

In this study, we used a 'Case 1' BWS to identify what carbon farming practices farmers in the case study region would be 'most likely' and 'least likely' to adopt (Finn and Louviere, 1992; Flynn and Marley, 2012) ${ }^{3}$. The survey was designed to gather information about the respondent, their farm business, attitudes toward climate change and preferences for carbon farming practices. We identified a range of carbon farming practices through a review of literature and interviews with experts in broadacre agriculture. Nine carbon sequestration practices, shown in Table 1, were selected for the mixed croplivestock and cropping-only farmers BWS surveys. Of the practices included in the BWS choice sets, planting trees and establishing areas of native vegetation were approved CFI methods at the time the survey was administered.

\footnotetext{
2 Sometimes also referred to as 'objects' or 'items'. In this paper we use the term 'element' to indicate the nine carbon farming practices available to respondents. We use the term 'option' to indicate the choice alternatives in one choice set.

${ }^{3}$ Flynn and Marley (2012) describe three types of BWS including Case 1 (the object case). The interested reader is referred to Flynn and Marley (2012) for further information about Case 1 BWS and other BWS approaches.
} 
Table 1. Carbon farming practices used in best-worst scaling choice sets

\begin{tabular}{ll}
\hline For cropping-only farmers & For mixed crop-livestock farmers \\
\hline Adopt no-till cropping practices & Adopt no-till cropping practices \\
Apply biochar & Apply biochar \\
Apply mulch to bare soil & Apply mulch to bare soil \\
Establish areas of native vegetation & $\begin{array}{l}\text { Increase the area dedicated to pasture (by } \\
\text { decreasing area dedicated to crops) }\end{array}$ \\
Inter-crop with perennial pastures & Inter-crop with perennial pastures \\
Plant perennial pastures & Plant perennial pastures \\
Plant tree belts & Plant tree belts \\
Plant trees for harvest (e.g. oil mallee) & Implement rotational grazing \\
Retain stubble after crop harvest & Retain stubble after crop harvest \\
\hline
\end{tabular}

Note: Establishing areas of native vegetation, planting trees for harvest, and planting tree belts were approved practices for participation in the Carbon Farming Initiative at the time the survey was distributed (providing specific criteria were met and a specific methodology was used to conduct the practice).

107 The survey consisted of four parts. The first part of the survey contained socio-demographic questions and questions about the respondent's farm size and type of farming system (e.g. mixed crop-livestock or cropping-only). The second part of the survey investigated farmers' opinions about climate change and attitudes towards carbon farming. The BWS choice questions were presented in the third part of the survey. Farmers were asked to think about carbon farming practices that they could adopt on their farm. We defined carbon farming as "practices that have the potential to capture (sequester) carbon in soils or vegetation for long periods of time". Each choice set presented six possible practices from which the respondent was asked to choose the one practice that they would be most likely to adopt, and the one practice they would be least likely to adopt. The BWS choice sets were constructed using a Balanced Incomplete Block Design (Street and Street, 1987). Each respondent was shown 12 choice sets, containing six of the nine possible practices in different combinations. An example choice set is shown in Figure 1.

[PLEASE INSERT FIGURE 1 ABOUT HERE, SIZE = 1.5 COLUMNS WIDE]

In the last section of the survey, information was gathered on the reasons for, or barriers to, adopting carbon farming practices, and opinions about current carbon farming policies. Respondents were also asked to rank (from 1-6) several "co-benefits" of carbon farming in order of importance to their decision to adopt carbon farming practices. The co-benefits presented to farmers were: improving soil quality, reducing soil erosion, enhancing biodiversity on farm, selling carbon credits, improving landscape appearance and greenhouse gas mitigation/carbon storage. 
126 The survey was programmed in the survey software Qualtrics (Qualtrics, 2013), and distributed online

127 to farmers in the northern wheatbelt area of Western Australia (Figure 2). The online survey link was

128 distributed via email by three farmer groups: Liebe Group, Mingenew Irwin Group, and the North East

129 Farming Futures Group. These groups have approximately 630 farm business members, and cover an

130 area of about 1.8 million hectares (GGA, 2015). An online distribution method was chosen for a number

131 of reasons, including to eliminate interviewer bias (Bateman and Mawby, 2004), ease of access to an

132 email database from the grower groups, ease of data collection, and demonstrated success in surveying

133 specialised groups with online surveys (e.g. Rogers, 2013). The survey responses were collected

134 between 3 August and 2 September 2013.

135 The survey was pre-tested with farmers from the North East Farming Futures group in Western

136 Australia. We asked a series of questions about the survey structure, length, and the carbon farming 137 practices included in the choice sets. Based on the feedback, we removed some questions, included

138 definitions of some terms and made the instructions for completing the BWS sets easier to interpret.

[PLEASE INSERT FIGURE 2 ABOUT HERE, SIZE = ONE COLUMN WIDE]

\subsection{Data analysis}

140 We use a parametric approach to analyse the BWS data. This approach is theoretically founded in

141 Random Utility Theory, which states that consumer $i$ chooses option $j$ that maximises their utility

142 (welfare), $U_{i j}$ (Manski, 1977). The statistical model underlying BWS assumes that the relative choice

143 probability of a given pair of elements is proportional to the distance between the two attribute levels on

144 the latent utility scale $U_{i j}$ (Flynn et al., 2007). Latent utility is composed of a deterministic component $V_{i j}$,

145 which can be observed through individuals' choices, and a stochastic, unobserved, error component $146 \varepsilon_{i j}$ :

$$
U_{i j}=V_{i j}+\varepsilon_{i j} \quad j=1,2, \ldots, J
$$

148 Our model explains utility $V_{i j}$ as a linearly additive function of the elements $X_{j}$ (carbon farming practices) 149 and interactions between the elements and individual socio-demographic characteristics $\left(Z_{i} X_{j}\right)$ :

$$
V_{i j}=\beta_{j} \cdot X_{j}+\beta_{i j} \cdot\left(Z_{i} \cdot X_{j}\right)
$$

Including socio-demographic variables in the model allows us to predict how individual characteristics influence preferences for the carbon farming practices included in the choice sets. 
Following a conventional approach in best-worst scaling (e.g. Glenk et al., 2014; Lancsar and Louviere, 2008), we assumed a sequential choice process. ${ }^{4}$ The probability that option $n$ is selected as the best option from the set of $J$ alternatives in the choice set is given by:

$$
\operatorname{Pr}_{i n_{1}}=\frac{\exp \left[\mu V_{i n_{1}}\right]}{\sum_{j=1}^{J} \exp \left[\mu V_{i j}\right]} \quad J=1,2, \ldots, 6
$$

Where $\mu$ is a scale parameter that is inversely proportional to the variance of the error term, typically normalised to one to enable estimation. The probability that option $n$ is selected as the worst option from the remaining $J$ alternatives is conditional on the choice of the best option:

$$
\operatorname{Pr}_{i n_{2} \mid n_{1}}=\frac{\exp \left[-\mu V_{i n_{2}}\right]}{\sum_{j=1}^{J} \exp \left[-\mu V_{i j}\right]} \quad J=1,2, \ldots, 5
$$

The probability of selecting $n_{1}$ as best and $n_{2}$ as worst is given by:

$$
P r_{i, n_{1}, n_{2}}=\operatorname{Pr}_{i n_{1}} \cdot \operatorname{Pr}_{i n_{2} \mid n_{1}}
$$

Which is analysed using a conditional logit regression model in Stata 13. Burge et al. (2011) explain that estimates from such conditional logit models are consistent, but that the standard errors need to be corrected to accommodate the non-independence of the data; i.e. there are relationships within choices made by the same respondent. To account for this panel nature of the data, we adjust the standard errors of our model using a sandwich estimator (Train, 2003, page 205). The sandwich estimator corrects the standard errors by clustering on the respondent's ID (Burge et al., 2011; Daly and Hess, 2011).

\section{Results}

\subsection{Sample characteristics}

A total of 43 survey responses were collected from individuals who manage a farm business. The median age of the respondents was 40 years old. This is younger than the median age (53) of Australian farmers in 2012 (Australian Bureau of Statistics, 2012). Most farmers (70 percent) identified as mixed crop-livestock farmers and the remaining 30 percent identified as cropping-only farmers. Most respondents ( 80 percent) said the farm was their only source of income (Table 2). Average farm size for mixed crop-livestock farmers was 7,100 ha (range 2,000 to 18,220) and for cropping-only farmers was 6,900 ha (range 2,000 to 23,500). Farms of this size are common in the low to medium rainfall zones in Western Australia (Planfarm, 2014). The mean area of cropped land per farm was 4,300 hectares and the mean area of pasture for livestock was 840 hectares. Crops grown by our respondents are common in the northern wheatbelt of Western Australia and include wheat, barley and canola, and in some areas, lupins.

\footnotetext{
${ }^{4}$ In our choice sets, the 'best' choice was presented on the left and the 'worst' choice on the right. Given that English language readers typically read from left to right (e.g. Tanzer and Hof, 2011) it is reasonable (and most common in BWS analysis) to assume that respondents first make their best choice, followed by their worst choice.
} 


\subsection{Opinions about climate change and carbon farming} We hypothesise that individual respondent's opinions about climate change and carbon farming policies may affect their preferences towards adopting carbon farming practices. In Table 2, we show the results of questions that aimed to capture respondents' opinions, experience and attitude toward climate change and climate change mitigation. Overall, 91 percent of farmers in our sample agreed with the statements "I believe climate change is occurring..." and the majority of these respondents agreed that climate change is (at least partly) caused by human activities (CC opinion; Table 2). This finding is in line with views found amongst the wider Australian population (Leviston et al., 2014). More than 60 percent of the survey respondents stated that they were experiencing impacts from climate change (Experiencing CC; Table 2). These respondents reported that they were experiencing decreased annual rainfall, prolonged and more pronounced drought events, higher average temperatures, shorter growing seasons, more extreme rainfall events, and a delayed start to the traditional growing season. About two-fifths of cropping-only farmers (38 percent) and more than half of the mixed crop-livestock farmers (57 percent) indicated that they had already changed their farm management in the past ten years to increase carbon sequestration. Changed farming practices that were identified include: minimum tillage, stubble retention, fewer fallow periods, fencing of remnant vegetation and trialling new vegetative species. Many of these practices are likely to have been adopted before the introduction of the CFI (e.g. Llewellyn and D'Emden, 2010). Therefore, awareness of the CFI (Aware of CFI; Table 2) has not necessarily affected the adoption of carbon farming practices. 
Table 2. Socio-demographic characteristics of the sample

\begin{tabular}{|c|c|c|c|}
\hline Variable & Response levels & $\begin{array}{l}\text { Mixed crop- } \\
\text { livestock (percent) }\end{array}$ & $\begin{array}{l}\text { Cropping-only } \\
\text { (percent) }\end{array}$ \\
\hline Area (hectares) & Average farm area (continuous variable) & 7123 & 6908 \\
\hline \multirow{5}{*}{$\begin{array}{l}\text { Age } \\
\text { (Respondents' } \\
\text { age in years) }\end{array}$} & 18 to 34 years & 30 & 30 \\
\hline & 35 to 44 years & 10 & 46 \\
\hline & 45 to 54 years & 20 & 8 \\
\hline & 55 to 64 years & 37 & 8 \\
\hline & 65 years and above & 3 & 8 \\
\hline \multirow{2}{*}{$\begin{array}{l}\text { Only source of } \\
\text { income } \\
(0 / 1)\end{array}$} & Farm business is main source of income $=1$ & 73 & 92 \\
\hline & $\begin{array}{l}\text { Income is supplemented by other incomes / Farm not } \\
\text { my main source of income }=0\end{array}$ & 27 & 8 \\
\hline \multirow{2}{*}{$\begin{array}{l}\text { Know others } \\
(0 / 1)\end{array}$} & $\begin{array}{l}\text { Know someone who is currently undertaking carbon } \\
\text { farming practices }=1\end{array}$ & 57 & 54 \\
\hline & (otherwise $=0$ ) & 43 & 46 \\
\hline \multirow{2}{*}{$\begin{array}{l}\text { Aware of } C F I \\
(0 / 1)\end{array}$} & Aware of the $\mathrm{CFI}=1$ & 40 & 38 \\
\hline & (otherwise $=0$ ) & 60 & 62 \\
\hline \multirow{2}{*}{$\begin{array}{l}\text { Appropriate } \\
(0 / 1)\end{array}$} & $\begin{array}{l}\text { Believe changes in farm practices are an appropriate } \\
\text { way to reduce Australia's GHG emissions }=1\end{array}$ & 33 & 23 \\
\hline & $\begin{array}{l}\text { I am unsure or do not believe changes in farm } \\
\text { practices are an appropriate way to reduce Australia's } \\
\text { GHG emissions }=0\end{array}$ & 67 & 77 \\
\hline \multirow{3}{*}{$\begin{array}{l}\text { CC Opinion } \\
(-1 / 0 / 1)\end{array}$} & $\begin{array}{l}\text { I don't believe climate change is occurring/ I am not } \\
\text { sure if climate change is occurring or not }=-1\end{array}$ & 6 & 15 \\
\hline & $\begin{array}{l}\text { I believe climate change is occurring and it is caused } \\
\text { by natural fluctuations in the Earth's temperature }=0\end{array}$ & 37 & 39 \\
\hline & $\begin{array}{l}\text { I believe climate change is occurring and it is partly } \\
\text { caused by human activities/ I believe climate change } \\
\text { is occurring and it is a result of human activities =1 }\end{array}$ & 57 & 46 \\
\hline \multirow{2}{*}{$\begin{array}{l}\text { Experiencing } \\
\text { CC } \\
(0 / 1)\end{array}$} & $\begin{array}{l}\text { I believe my farm business is experiencing the } \\
\text { impacts of climate change }=1\end{array}$ & 63 & 62 \\
\hline & $\begin{array}{l}\text { I am unsure or do not believe my farm business is } \\
\text { experiencing the impacts of climate change }=0\end{array}$ & 37 & 38 \\
\hline \multirow{2}{*}{$\begin{array}{l}\text { Already } \\
\text { changed } \\
\text { practices } \\
(0 / 1)\end{array}$} & $\begin{array}{l}\text { I have changed my farm management in the past } 10 \\
\text { years to increase carbon storage in vegetation and/or } \\
\text { soils }=1\end{array}$ & 57 & 38 \\
\hline & $\begin{array}{l}\text { I have not changed my farm management in the past } \\
10 \text { years to increase carbon storage in vegetation } \\
\text { and/or soils }=0\end{array}$ & 43 & 62 \\
\hline \multirow{3}{*}{$\begin{array}{l}\text { Policies are } \\
\text { encouraging } \\
(-1 / 0 / 1)\end{array}$} & $\begin{array}{l}\text { The carbon farming policies will not help to encourage } \\
\text { farmers to sequester carbon on their land }=-1\end{array}$ & 16 & 46 \\
\hline & $\begin{array}{l}\text { I am unsure whether the carbon farming policies will } \\
\text { help to encourage farmers to sequester carbon on } \\
\text { their land }=0\end{array}$ & 57 & 46 \\
\hline & $\begin{array}{l}\text { The carbon farming policies will help to encourage } \\
\text { farmers to sequester carbon on their land }=1\end{array}$ & 27 & 8 \\
\hline
\end{tabular}

Note: Variable names used in column 1 are repeated in Table 3 and Table 4 when presenting regression results using these socio-demographic factors. 
Farmers were asked to rank the importance of six carbon farming co-benefits in their decision to adopt carbon farming practices (from $1=$ most important to $6=$ least important, Figure 3 ). There was no difference between the ranking given by mixed crop-livestock farmers and cropping-only farmers (chisquare value of $4.81, \mathrm{p}$-value of 0.439 ). Improving soil quality by sequestering carbon was ranked as the most important benefit (relative to the other potential benefits presented) by 73 percent of mixed crop-livestock farmers and by 77 percent of cropping-only farmers. The opportunity to mitigate emissions and to sell carbon credits did not appear to be important benefits of carbon farming from the farmers' perspective. Improved soil quality may thus drive a farmer's decision, with any GHG mitigation that might be achieved as a spin-off (auxiliary) benefit.

\section{[PLEASE INSERT FIGURE 3 ABOUT HERE, SIZE = 1.5 COLUMNS WIDE]}

213 Farmers who had not changed their practices to increase carbon storage in vegetation and/or soils in the last 10 years (see Table 2) were also asked to nominate the three factors that have so far discouraged them from doing so. The most common barriers to adoption were: uncertainty about policies (66 percent), uncertainty about the possible practices and the potential effects of those on the farm business (61 percent), uncertainty about the price of carbon ( 57 percent) and the buyers in the carbon market (52 percent).

\subsection{Preferences for carbon farming practice adoption}

220 Reponses to the BWS questions can be used to rank the 'willingness to adopt' carbon farming practices 221 (relative to the other carbon farming practices presented in the BWS choice sets) for the aggregated 222 survey sample. To assess whether the choices for different elements depend on the levels of other 223 variables, we create new 'interaction variables' as per equation 2. Each socio-demographic and attitude variable (Table 2) was interacted with each of the nine carbon farming elements. The conditional logit

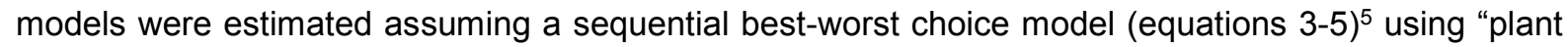
perennial pastures" as the reference item. A positive coefficient for an element thus indicates that the practice is preferred relative to planting perennial pastures, a negative coefficient indicates that the farmer is less willing to adopt the practice relative to planting perennial pastures.

\subsubsection{Mixed crop-livestock farmers}

230 The results from the conditional logit models for mixed crop-livestock farmers are provided in Table 3. When accounting for socio-demographic and attitudinal factors the practices that mixed crop-livestock farmers were most likely to adopt were retaining stubble and rotational grazing. There were no significant differences in the stated 'willingness to adopt' perennial pastures, no-till cropping and increasing the area dedicated to pasture. Inter-cropping with perennial pastures, applying mulch,

\footnotetext{
${ }^{5}$ More complex random parameter models were also estimated but did not alter the main conclusions. Results from the RPL models are available upon request from the authors.
} 
planting tree belts and applying biochar were less likely to be adopted (compared to perennial pastures)

236 by mixed crop-livestock farmers. Mixed crop-livestock farmers who were aware of the CFI had lower

237 than average 'willingness to adopt' scores for no-till cropping, and higher than average 'willingness to

238 adopt' scores for applying mulch to soil (Table 3). Older farmers had a greater willingness to adopt no-

239 till cropping, apply biochar and plant tree belts. However, those who knew other farmers who had

240 implemented a carbon farming practice were less likely to plant tree belts compared to farmers that did

241 not know other carbon farmers (Table 3).

Table 3. Conditional logit model estimates for the influence of socio-demographic variables on carbon farming adoption preferences of mixed crop-livestock farmers.

\begin{tabular}{|c|c|c|c|}
\hline Carbon farming practice & Coefficient & St. Error $\mathrm{x}$ & P value \\
\hline Retain stubble after crop harvest & 3.56 & 0.485 & 0.000 \\
\hline Implement rotational grazing & 1.85 & 0.774 & 0.017 \\
\hline Adopt no-till cropping & 0.10 & 0.903 & 0.916 \\
\hline Plant perennial pastures (reference practice) & 0.00 & ences & . \\
\hline Increase area dedicated to pasture & -0.54 & 0.344 & 0.119 \\
\hline Inter-crop with perennial pastures & -0.73 & 0.250 & 0.003 \\
\hline Apply mulch to bare soil & -1.92 & 0.459 & 0.000 \\
\hline Plant tree belts & -2.35 & 1.040 & 0.024 \\
\hline Apply biochar & -4.73 & 1.334 & 0.000 \\
\hline Interactions with SD variables & $\begin{array}{l}\text { Interaction } \\
\text { Coefficient }\end{array}$ & St. Error & $\begin{array}{c}\mathbf{P} \\
\text { value }\end{array}$ \\
\hline Retain stubble $\times$ Appropriate & -1.78 & 0.604 & 0.003 \\
\hline Implement rotational grazing $\times \mathrm{Age}^{\dagger}$ & -0.04 & 0.016 & 0.011 \\
\hline Adopt no-till cropping $x$ Age & 0.05 & 0.019 & 0.004 \\
\hline Adopt no-till cropping $\times$ Aware of CFI & -1.74 & 0.813 & 0.010 \\
\hline Plant tree belts $\times$ Know others & -1.80 & 0.700 & 0.010 \\
\hline Apply mulch to bare soil $x$ Aware of CFI & 1.35 & 0.624 & 0.030 \\
\hline Plant tree belts $\times$ Age & 0.06 & 0.022 & 0.011 \\
\hline Apply biochar x Age & 0.04 & 0.024 & 0.085 \\
\hline Apply biochar x Area ('000s of hectares) & 0.17 & 0.073 & 0.018 \\
\hline Number of observations ${ }^{\ddagger}$ & 720 & & \\
\hline Log likelihood & -785.29 & & \\
\hline Pseudo R2 & 0.359 & & \\
\hline
\end{tabular}

Notes: Socio-demographic and attitudinal variables and their levels are defined in Table 2.

Adoption preferences are relative to adopting perennial pastures. $\times$ Standard errors were corrected for 30 clusters (respondents) to account for multiple choice observations per respondent. ${ }^{\dagger}$ For the regressions, the age variable was converted into a continuous variable using the mid-point of each category and 65 years for the top-category. $¥$ The 30 farmers completed one best and one worst choice in each of the in 12 choice sets, leading to 24 choice observations per respondent.

\subsubsection{Cropping-only farmers}

243 When accounting for socio-demographic and attitudinal factors the practices that cropping-only farmers 244 were most willing to adopt were retaining stubble, no-till cropping practices and applying mulch (Table

245 4). The practice that cropping-only farmers were least willing to adopt was planting trees for harvest.

246 There were no significant differences in the farmers' stated willingness to plant perennial pastures, plant 247 tree belts, inter-crop with perennial pastures, apply biochar or establish areas of native vegetation.

248 Farmers who were already experiencing negative impacts of climate change had a higher 'willingness 249 to adopt' score for planting trees for harvest compared to farmers who said they had not experienced 250 any impacts of climate change. Cropping-only farmers who believed humans are at least partially 251 contributing to climate change had higher than average 'willingness to adopt' scores for applying mulch, 
adopting no-till cropping practices and planting tree belts. Cropping only farmers who were aware of

253 the CFI were less willing to apply mulch and plant trees belts compared to farmers who were not aware 254 of the CFI. Farmers who believed carbon farming is an appropriate way to reduce Australia's GHG 255 emissions, had lower than average 'willingness to adopt' scores for applying mulch.

Table 4. Conditional logit model estimates for the influence of socio-demographic variables on carbon farming adoption preferences of cropping-only farmers.

\begin{tabular}{|c|c|c|c|}
\hline Carbon farming practice & Coefficient & St. Errorx & P value \\
\hline Retain stubble after crop harvest & 4.24 & 0.513 & 0.000 \\
\hline Adopt no-till cropping & 3.50 & 0.526 & 0.000 \\
\hline Apply mulch to bare soil & 0.80 & 0.312 & 0.011 \\
\hline Plant tree belts & 0.47 & 0.552 & 0.394 \\
\hline Plant perennial pastures (reference practice) & 0.00 & . & 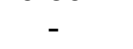 \\
\hline Inter-crop with perennial pastures & -0.08 & 0.384 & 0.835 \\
\hline Apply biochar & -0.97 & 0.549 & 0.079 \\
\hline Establish areas of native vegetation & -1.31 & 1.270 & 0.304 \\
\hline Plant trees for harvest & -1.57 & 0.577 & 0.006 \\
\hline Interaction with SD variables & $\begin{array}{l}\text { Interaction } \\
\text { coefficient }\end{array}$ & St. Error & $\begin{array}{c}\mathbf{P} \\
\text { value }\end{array}$ \\
\hline Adopt no-till cropping x CC Opinion & 1.35 & 0.750 & 0.073 \\
\hline Establish areas of native veg $\times$ Area ('000s of hectares) & 0.16 & 0.094 & 0.079 \\
\hline Apply mulch to bare soil x CC Opinion & 0.80 & 0.416 & 0.053 \\
\hline Apply mulch to bare soil $x$ Aware of the CFI & -1.48 & 0.539 & 0.006 \\
\hline Apply mulch to bare soil $\times$ Appropriate & -2.19 & 0.982 & 0.025 \\
\hline Plant tree belts $x$ CC Opinion & 1.00 & 0.295 & 0.001 \\
\hline Plant tree belts $x$ Aware of the CFI & -1.05 & 0.468 & 0.025 \\
\hline Establish areas of native vegetation $\times$ Know others & 1.96 & 1.126 & 0.083 \\
\hline Plant trees for harvest $x$ Experiencing $C C$ & 1.94 & 1.042 & 0.063 \\
\hline Plant trees for harvest $x$ Policies are encouraging & -3.67 & 0.917 & 0.000 \\
\hline Number of observations $\ddagger$ & 312 & & \\
\hline Log likelihood & -296.25 & & \\
\hline Pseudo R2 & 0.442 & & \\
\hline
\end{tabular}

Notes: Socio-demographic and attitudinal variables and their levels are defined in Table 2. Adoption preferences are relative to adopting perennial pastures. x Standard errors were corrected for 13 clusters (respondents) to account for multiple choice observations per respondent. $¥$ The 13 farmers completed one best and one worst choice in each of the in 12 choice sets, leading to 24 choice observations per respondent.

\section{Discussion and conclusion}

257 The carbon farming practice that was, overwhelmingly, preferred by both cropping and mixed crop258 livestock farmers surveyed was retaining stubble after crop harvest. Alongside retaining stubble, mixed 259 farmers stated a preference to implement rotational grazing. Both practices can provide improved 260 grazing options for livestock, which form a significant part of the mixed crop-livestock farm business. 261 Livestock grazing was allocated, on average 20 percent (range 6 to 65 percent) of farm area in the 262 survey sample, a result in line with the average mixed crop-livestock farm in Western Australia (Kragt 263 et al., 2012; Kragt and Robertson, 2014). Cropping-only farmers also indicated a high likelihood of 264 adopting no-till cropping practices. The high preference for retaining stubble and no-till cropping are 265 likely to reflect farmers' perceptions of the production co-benefits associated with these two practices. 266 Both stubble retention and no-till cropping have been found to positively impact soil quality, which can 267 subsequently have a positive impact on crop yield (Lal, 2004). The relationship between production 268 benefits and likelihood of adoption is further confirmed by respondents ranking 'improved soil quality' 
and 'reduced soil erosion' as the most important co-benefits to be derived from carbon farming. The willingness to adopt no-till and stubble retention could also be attributed to the ease with which these practices can be included into standard broadacre farming operations. In comparison, practices that do not readily fit within the existing farm enterprise mix (e.g. applying biochar) received lower scores in our study. Practices that require an even larger change to the farming system, such as establishing areas of native vegetation or tree plantings, were also often chosen as 'least likely to adopt' by respondents to our survey.

The implementation of a carbon farming practice on a neighbouring property could demonstrate success, as in the case of stubble retention and no-till cropping, but also failure. For example, whilst tree belts have positive impacts on soil carbon, there is evidence that trees compete with crops for water and nutrients, consequently reducing crop yields (Sudmeyer et al., 2012). If such negative impacts are demonstrated on neighbouring properties where tree belts have been planted, farmers may be less willing to also plant trees. We recommend that, to increase the adoption of carbon farming in Australia, the feasibility and profitability of changing practices be demonstrated clearly through farm trials or other extension programs. The CFI was initially accompanied by the Carbon Farming Futures program that funded research trials and extension to farmers, with the aim to demonstrate how carbon farming practices can be incorporated in profitable farming systems (DCCEE, 2011). Our results suggest that such programs will be essential to achieve more wide-spread adoption of carbon farming into the future.

We show that farmers' preferences for changed land management vary with their opinions about climate change and experience with the CFI. Whether farmers perceive to experience negative impacts of climate change, and their belief that humans are (at least partly) contributing to climate change, affects farmers' stated likelihood to adopt some of the carbon farming practices included in our research. Experiencing negative impacts of climate change had a positive influence on the preferences of cropping-only farmers to plant trees for harvest. This could be a result of the higher proportion of cropping-only farmers being located in the most marginal areas of the West Australian wheatbelt, which is experiencing the greatest impact of declining rainfall and increasing temperatures (Asseng and Pannell, 2013). In such marginal areas, carbon farming may well provide an alternative income source, rather than be seen as competing with traditional broadacre farming practices. These results are likely to be indicative for other grain growing regions in Mediterranean climate regions that have experienced similar negative impacts of climate change (such as drought-prone regions in Southern Australia, and Mediterranean farming regions in Spain or Portugal).

Awareness and understanding of the Carbon Farming Initiative had an impact on preferences. Cropping-only farmers aware of the policy were less likely to apply mulch and plant tree belts, than cropping-only farmers that were unaware of the policy. This is not desirable given the policy aims to encourage adoption of these practices. We further found that less than 35 percent of respondents agreed that carbon farming is an appropriate way to reduce Australia's GHG emissions. It appears that 
farmers' willingness to adopt carbon farming practices may well be hindered by their attitudes and understanding of the policy framework.

308 It is interesting to note that the opportunity to generate carbon credits was not an important driver to adopt carbon farming practices for the farmers that were surveyed. This finding continues to support the common theme in the results, practices with demonstrable environmental co-benefits or benefits for farm productivity are most likely to be adopted and they are most likely to be adopted as a result of the private benefits they can provide. Practices that fit within the existing farming system are also more likely to be widely adopted relative to practices that require changes to the farm enterprise mix. If we aim to achieve widespread adoption of carbon farming practices, we require flexible policies that allow farmers to select the carbon farming practices that are most appropriate for their farm system and their management strategy (Jones et al., 2013). This may create a case for providing more information and extension services that target specific groups of farmers based on their farm enterprise mix and location. Furthermore, if the government wants to increase the farming community's support for carbon farming policies, it will be important to communicate the co-benefits from carbon farming and synergies with existing farm management practices, rather than highlighting the opportunity to earn carbon credits through a voluntary carbon offset market.

Policy uncertainty has continued since this survey was conducted. Under the newly introduced Emissions Reduction Fund, the government intends to purchase the lowest cost abatement through a reverse auction system. Logically, we will most likely see businesses with the capacity to implement new practices in a cost-effective manner and achieve credible emissions reductions to be the ones to participate in the scheme. The challenge for farmers looking to engage in the scheme is to know what carbon farming practices are able to deliver low cost abatement, and how much it will cost them to implement the necessary changes to their farm system. These unavoidable transaction costs will likely remain an obstacle to participation alongside the policy uncertainty. We have shown that production and profitability benefits are the major motivations for farmers to adopt carbon farming practices. Research is ongoing to determine the benefits of adopting climate change mitigation practices on broadacre cropping farms, and the cost effectiveness of carbon farming practices to achieve emissions mitigation.

\section{References}

Asseng, S., Pannell, D.J., 2013. Adapting dryland agriculture to climate change: Farming implications and research and development needs in Western Australia. Climatic Change 118, 167-181.

337 Australian Bureau of Statistics, 2012. Australian farming and farmers. Australian Bureau of Statistics, 338 Canberra.

Barr, N., Cary, J., 2000. Influencing Improved Natural Resource Management on Farm: A guide to understanding factors influencing the adoption of sustainable resource practice. Bureau of Rural Sciences, Canberra, ACT. Stated Preference Techniques: A Manual. Edward Elgar, Cheltenham. 
Bateman, I.J., Mawby, J., 2004. First impressions count: interviewer appearance and information effects in stated preference studies. Ecological Economics 49, 47-55.

Bradshaw, C.J.A., Bowman, D.M.J.S., Bond, N.R., Murphy, B.P., Moore, A.D., Fordham, D.A., Thackway, R., Lawes, M.J., McCallum, H., Gregory, S.D., Dalal, R.C., Boer, M.M., Lynch, A.J.J., Bradstock, R.A., Brook, B.W., Henry, B.K., Hunt, L.P., Fisher, D.O., Hunter, D., Johnson, C.N., Keith, D.A., Lefroy, E.C., Penman, T.D., Meyer, W.S., Thomson, J.R., Thornton, C.M., VanDerWal, J., Williams, R.J., Keniger, L., Specht, A., 2013. Brave new green world - Consequences of a carbon economy for the conservation of Australian biodiversity. Biological Conservation 161, 71-90.

351

352

353

354

355

356

357

358

359

360

361

362

363

364

365

366

367

368

369

370

371

372

373

374

375

376

377

378

379

380

381

382

383

384

385

386

387

388

389

390

391

392

393
Burge, P., Potoglou, D., Flynn, T.N., Brazier, J.E., Netten, A., 2011. Best-worst scaling: Consistency of preferences with discrete choice experiments and stability over time. International Choice Modelling Conference, Leeds, UK, 4-6 July 2011.

Climate Change Authority, 2014. Reducing Australia's Greenhouse Gas Emissions-Targets and Progress Review, Australian Government, Canberra.

Coltman, T., Devinney, T., Keating, B., 2010. Best-worst scaling approach to predict customer choice for 3PL services. Journal of Business Logistics 32, 139-152.

Cross, P., Rigby, D., Edwards-Jones, G., 2012. Eliciting expert opinion on the effectiveness and practicality of interventions in the farm and rural environment to reduce human exposure to Escherichia coli O157. Epidemiology \& Infection 140, 643-654.

Daly A, Hess S, 2011. Simple Approaches for Random Utility Modeling with Panel Data. 90th Annual Meeting of the Transportation Research Board, Washington DC, USA.

Davis, K.J., Kragt, M.E., Gelcich, S., Schilizzi, S., Burton, M., Pannell, D., 2015. What prevents fishers from enforcing their user rights?, Working Paper 1510, School of Agricultural and Resource Economics, University of Western Australia, Crawley, Australia.

DCCEE, 2011. Securing a clean energy future: The Australian Government's climate change plan. Department of Climate Change and Energy Efficiency, Australian Government, Canberra.

DCCEE, 2012. The Carbon Farming Initiative Handbook. Department of Climate Change and Energy Efficiency, Australian Government, Canberra.

Department of the Environment, 2015a. Australia's 2030 Emissions Reduction Target. Department of the Environment, Australian Government, Canberra

Department of the Environment, 2015b. Australian National Greenhouse Accounts Quarterly Update of Australia's National Greenhouse Gas Inventory, March Quarter 2015. Department of the Environment, Australian Government, Canberra.

Desjardins, R., Smith, W., Grant, B., Campbell, C., Riznek, R., 2005. Management Strategies to Sequester Carbon in Agricultural Soils and to Mitigate Greenhouse Gas Emissions. Climatic Change 70, 283-297.

Erdem, S., Rigby, D., Wossink, A., 2012. Using Best-Worst Scaling to Explore Perceptions of Relative Responsibility for Ensuring Food Safety. Food Policy 37, 661-670.

Finn, A., Louviere, J.J., 1992. Determining the Appropriate Response to Evidence of Public Concern: The Case of Food Safety. Journal of Public Policy \& Marketing 11, 12-25.

Flynn, T., N., Marley, A., J., 2012. Best Worst Scaling: Theory and Methods. Working paper 12-002. University of Technology Sydney.

Flynn, T.N., Louviere, J.J., Peters, T.J., Coast, J., 2007. Best-worst scaling: What it can do for health care research and how to do it. Journal of Health Economics 26, 171-189.

Flynn, T.N., Louviere, J.J., Peters, T.J., Coast, J., 2008. Estimating preferences for a dermatology consultation using Best-Worst Scaling: Comparison of various methods of analysis. BMC Medical Research Methodology 8 (76).

George, S.J., Harper, R.J., Hobbs, R.J., Tibbett, M., 2012. A sustainable agricultural landscape for Australia: A review of interlacing carbon sequestration, biodiversity and salinity management in agroforestry systems. Agriculture, Ecosystems and Environment 163, 28-36. 
GGA, 2015. Grower Groups: Northern Agricultural Region, Grower Group Alliance, South Perth, Western Australia.

Glenk, K., Colombo, S., 2011. How Sure Can You Be? A Framework for Considering Delivery Uncertainty in Benefit Assessments Based on Stated Preference Methods. Journal of Agricultural Economics 62, 25-46.

Glenk, K., Eory, V., Colombo, S., Barnes, A., 2014. Adoption of greenhouse gas mitigation in agriculture: An analysis of dairy farmers' perceptions and adoption behaviour. Ecological Economics 108, 49-58.

402

403

Jones, A.K., Jones, D.L., Edwards-Jones, G., Cross, P., 2013. Informing decision making in agricultural greenhouse gas mitigation policy: A Best-Worst Scaling survey of expert and farmer opinion in the sheep industry. Environmental Science \& Policy 29, 46-56.

405

406

Knowler, D., Bradshaw, B., 2007. Farmers' adoption of conservation agriculture: A review and synthesis of recent research. Food Policy 32, 25-48.

407

408

Kragt, M.E., Blackmore, L., Capon, T., Robinson, C.J., Torabi, N., Wilson, K.A., 2014. What are the barriers to adopting carbon farming practices?, Working Paper 1407, School of Agricultural \& Resource Economics, University of Western Australia, Crawley, Australia.

410

Kragt, M.E., Pannell, D.J., Robertson, M.J., Thamo, T., 2012. Assessing costs of soil carbon sequestration by crop-livestock farmers in Western Australia. Agricultural Systems 112, 27-37.

412

Kragt, M.E., Robertson, M.J., 2014. Quantifying ecosystem services trade-offs from agricultural practices. Ecological Economics 102, 147-157.

414 Lal, R., 2004. Soil Carbon Sequestration Impacts on Global Climate Change and Food Security. 415 Science 304, 1623-1627.

Lancsar, E., Louviere, J., 2008. Estimating individual level discrete choice models and welfare measures using best worst choice experiments and sequential best worst MNL. Working Paper Series, No. 08-003. Centre for the Study or Choice (CenSoc), University of Sydney.

Lee, J.A., Soutar, G.N., Louviere, J., 2007. Measuring Values Using Best-Worst Scaling: The LOV Example. Psychology \& Marketing 24, 1043-1058.

Leviston, Z., Price, J., Malkin, S., McCrea, R., 2014. Fourth annual survey of Australian attitudes to climate change: Interim report. CSIRO, Perth, Australia.

Llewellyn, R.S., D'Emden, F.H., 2010. Adoption of no-till cropping practices in Australian grain growing regions. Grains Research and Development Corporation, Canberra.

Macintosh, A., 2013. The Carbon Farming Initiative: removing the obstacles to its success. Carbon Management 4, 185-202.

MacKerron, G.J., Egerton, C., Gaskell, C., Parpia, A., Mourato, S., 2009. Willingness to pay for carbon offset certification and co-benefits among (high-)flying young adults in the UK. Energy Policy 37, 13721381.

430 Manski, C.F., 1977. The structure of random utility models. Theory and Decision 8, 229-254.

Marti, J., 2012. A best-worst scaling survey of adolecents' level of concern for health and non-health consequences of smoking. Social Science \& Medicine 75, 87-97.

Morgan, M.I., Hine, D.W., Bhullar, N., Loi, N.M., 2015. Landholder adoption of low emission agricultural practices: a profiling approach. Journal of Environmental Psychology 41, 35-44.

435 Page, G., Bellotti, B., 2015. Farmers value on-farm ecosystem services as important, but what are the impediments to participation in PES schemes? Science of the Total Environment 515-516, 12-19.

Pannell, D.J., Marshall, G.R., Barr, N., Curtis, A., Varclay, F., Wilkinson, R., 2006. Understanding and promoting the adoption of conservation practices by rural landholders. Australian Journal of Experimental Agriculture 46, 1407-1424.

440 Parliament of the Commonwealth of Australia, 2011. Carbon Credits (Carbon Farming Initiative) Bill, 441 Explanatory Memorandum. Parliament of the Commonwealth of Australia, Canberra, ACT. 
442 Parliament of the Commonwealth of Australia, 2014. Carbon Farming Initiative Amendment Bill, 443 Explanatory Memorandum. Parliament of the Commonwealth of Australia, Canberra, ACT.

444 Perring, M.P., Standish, R.J., Hulvey, K.B., Lach, L., Morald, T.K., Parsons, R., Didham, R.K., Hobbs, 445 R.J., 2012. The Ridgefield Multiple Ecosystem Services Experiment: Can restoration of former 446 agricultural land achieve multiple outcomes? Agriculture, Ecosystems and Environment 163, 14-27.

447 Planfarm, 2014. Planfarm Bankwest Benchmarks 2013-2014, Planfarm, Wembley, Western Australia.

448 Qualtrics, 2013. Qualtrics software, version 58307, Provo, Utah, USA.

449 Rodríguez-Entrena, M., Espinosa-Goded, M., Barreiro-Hurlé, J., 2014. The role of ancillary benefits on 450 the value of agricultural soils carbon sequestration programmes: Evidence from a latent class approach 451 to Andalusian olive groves. Ecological Economics 99, 63-73.

452 Rogers, A.A., 2013. Public and Expert Preference Divergence: Evidence from a Choice Experiment of 453 Marine Reserves in Australia. Land Economics 89, 346-370.

454 Smith, P., Martino, D., Cai, Z., Gwary, D., Janzen, H., Kumar, P., McCarl, B., Ogle, S., O'Mara, F., Rice, 455 C., Scholes, B., Sirotenko, O., Howden, M., McAllister, T., Pan, G., Romanenkov, V., Schneider, U., 456 Towprayoon, S., Wattenbach, M., Smith, J., 2008. Greenhouse Gas Mitigation in Agriculture. 457 Philosophical Transactions: Biological Sciences 363, 789-813.

458 Street, D., Street, A., 1987. Combinatorics of Experimental Design. Clarendon Press, Oxford.

459 Sudmeyer, R.A., Daniels, T., Jones, H., Huxtable, D., 2012. The extent and cost of mallee-crop 460 competition in unharvested carbon sequestration and harvested mallee biomass agroforestry systems. 461 Crop \& Pasture Science 63, 555-569.

462 Tanzer, N.K., Hof, J., 2011. Language-related biases in nonverbal intelligence tests, 11th European 463 Conference on Psychological Assessment, Riga, Latvia. 31 August - 3 September 2011.

464 Train, K.E.. 2003. Discrete Choice Methods with Simulation. Cambridge University Press, Cambridge. 
Figures

465

\begin{tabular}{c|c|c}
\hline MOST likely to adopt & Carbon farming practice & LEAST likely to adopt \\
\hline$\square$ & Retain crop stubble after harvest & $\square$ \\
$\square$ & Apply biochar & $\square$ \\
$\square$ & Plant tree belts & $\square$ \\
$\square$ & Plant perennial pastures & $\square$ \\
$\square$ & Apply mulch to bare soil & $\square$ \\
$\square$ & Adopt no-till cropping & $\square$ \\
\hline
\end{tabular}

466

Figure 1. An example of a best-worst scaling choice set used in this study

467 


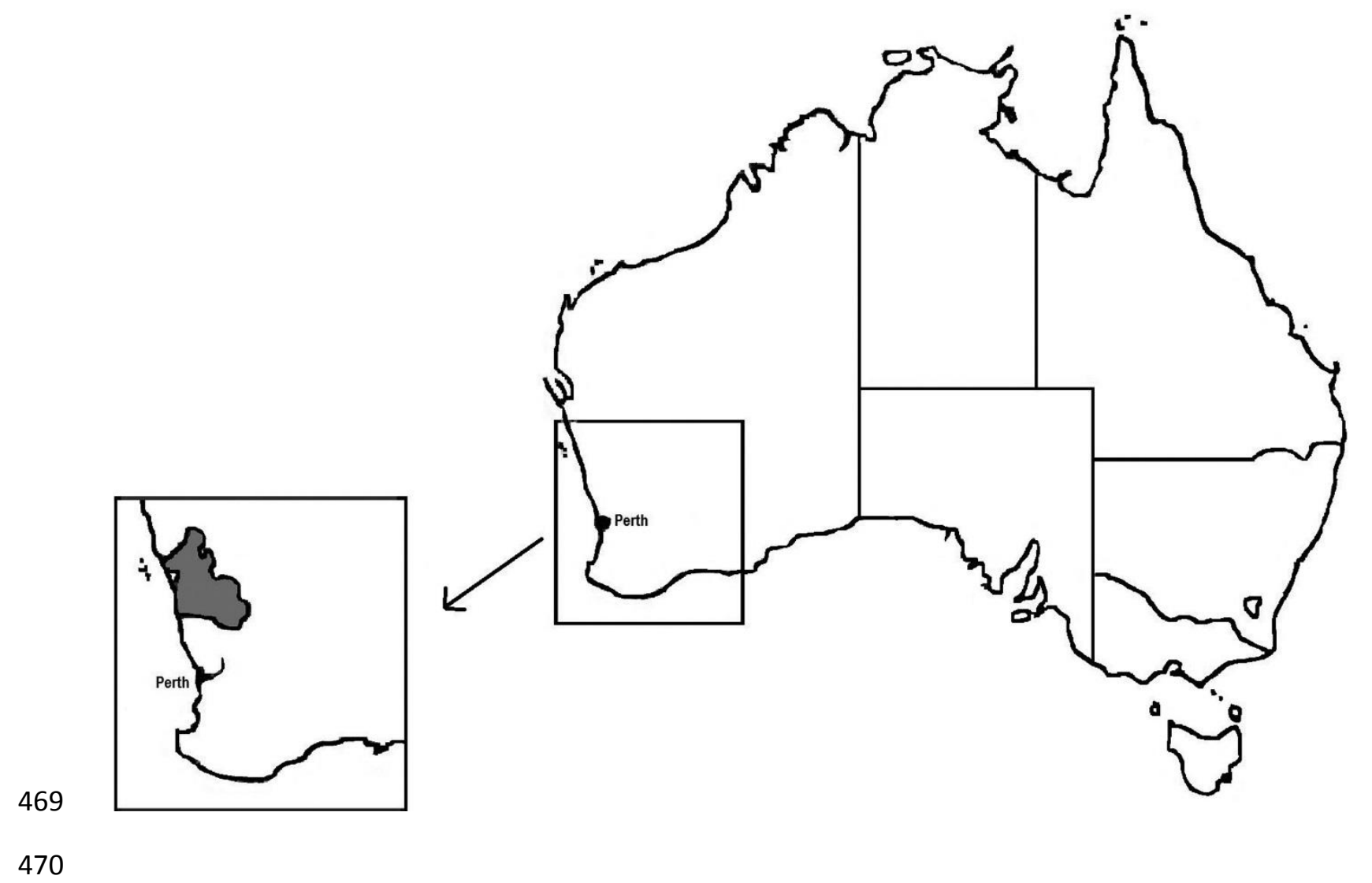

Figure 2. Study region (shaded), northern wheatbelt of Western Australia 471 


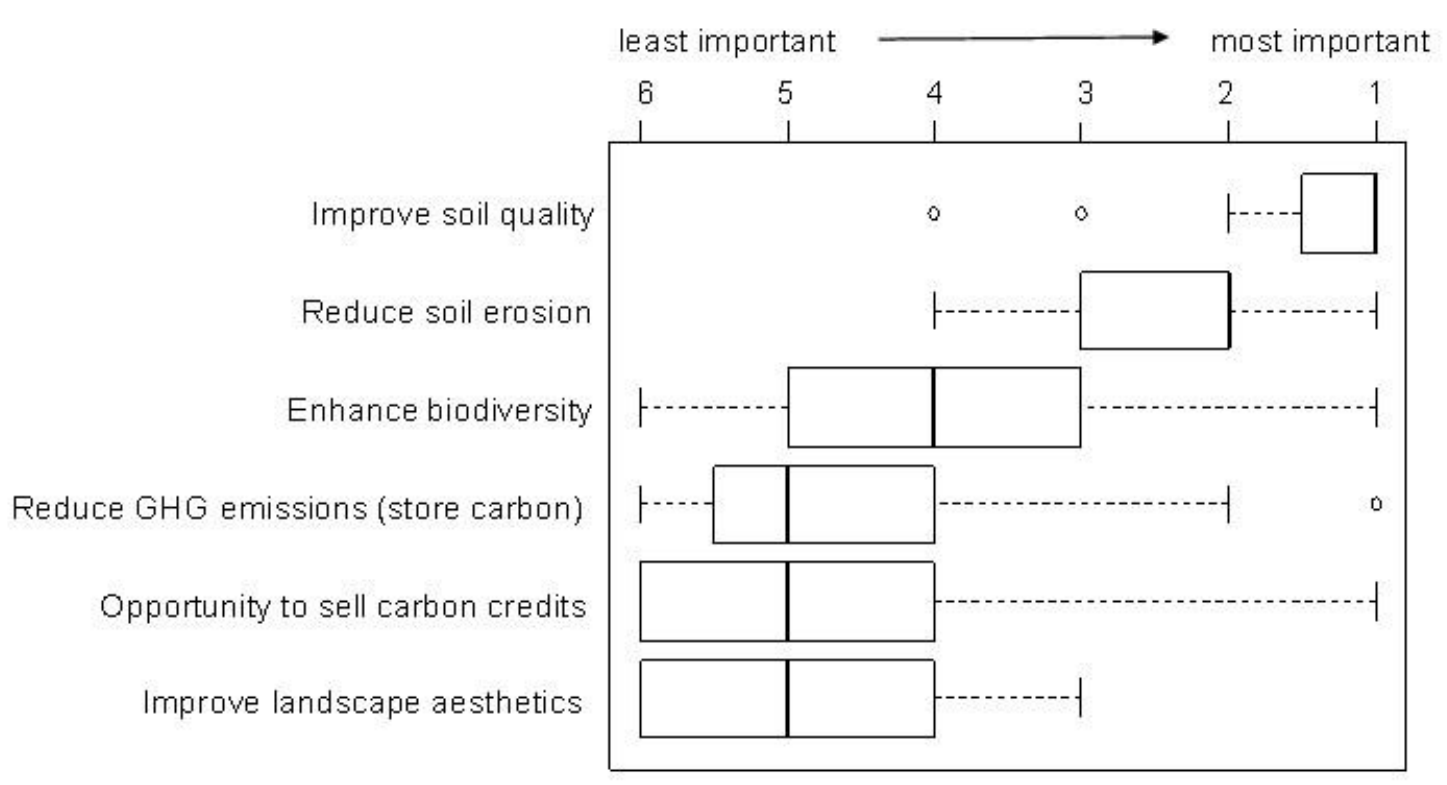

473

Figure 3. Relative importance that farmers placed on six potential benefits of carbon farming. The box plot indicates the 25th, 50th and 75th percentiles and the standard deviation of the ranking position (1-6) for each benefit. The most important benefit is ranked as number 1 . 